\title{
Use of NOAA-AVHRR data to monitor snow cover and spring meltoff in the wildlife habitats in Jameson Land, East Greenland
}

\author{
BIRGER ULF HANSEN and ANDERS MOSBECH
}

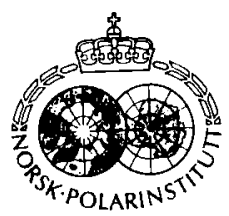

Hansen, B. U. \& Mosbech, A. 1994: Use of NOAA-AVHRR data to monitor snow cover and spring meltoff in the wildlife habitats in Jameson Land, East Greenland. Polar Research 13, 125-137.

NOAA-AVHRR satellite data have been used for a multi-year analysis of the seasonal variation of snow cover on the peninsula of Jameson Land located from $70^{\circ} 30^{\prime} \mathrm{N}$ to $72^{\circ} \mathrm{N}$ on the eastern coast of Greenland. Monitoring programmes for muskoxen and geese populations in Jameson Land were started in the early 1980 s to assess the impact of oil exploration in the area. This study was conducted to provide snow cover data to the wildlife monitoring programmes because snow cover is an important factor which can affect the numbers and distribution of muskoxen and other wildlife in the area.

Snow cover mapping is based on the geometric correction and radiometric calibration of each satellite scene before the visual bands are corrected for the terrain-effects and high solar zenith angle by using a simple radiation model. The atmospheric effect on the thermal infrared bands is corrected by using the "split-window" method. An automatic filtering routine with empirically determined thresholds is used to determine cloud- and haze-covered areas before the snow cover is computed from a linear expression using albedos of bare ground and full snow cover. By combining the satellite information with ground measurements and a digital terrain model, both the spatial distribution of snow cover and the total snow cover depletion can be obtained.

The method makes it possible to analyse the variation in regional and seasonal snow cover in wildlife habitats. The variation in snow cover depletion has been analysed in five subareas in the muskox area, and the results indicate that the snow cover pattern is an important factor which influences muskox calf crop and regional distribution of the muskox population. The method has proved useful for monitoring the duration of snow cover, and its application ought to facilitate the future study of wildlife habitats in extensive alpine and arctic areas.

Birger Ulf Hansen, Institute of Geography, University of Copenhagen, Oster Voldgade 10, DK-1350 Copenhagen K, Denmark; Anders Mosbech, Greenland Environmental Research Institute, Tagensvej 135, DK-2200 Copenhagen N, Denmark.

\section{Introduction}

Until recently, most snow cover data and other meteorological parameters pertaining to the arctic region originated from just a few manned meteorological stations scattered along the coast. Such data were often only applicable to a limited and local area. In the last 25 years, the great upsurge of interest in global change studies has increased world interest in the arctic region and its vulnerable environment, but it has also served to emphasise the lack of understanding of even the most fundamental arctic parameters due to the sparsity of conventional meteorological data. Fortunately, however, this new interest has coincided with great advances in satellite platforms and sensors. Today remotely-sensed data make a substantial contribution to the meteorological database, and satellite remote sensing offers the only realistic method of obtaining the systematic, repetitive and reliable coverage required by many arctic studies.

In this paper, a method for monitoring snow cover with NOAA-AVHRR (National Oceanographic and Atmospheric Administration Advanced Very High Resolution Radiometer) satellite data is generated and tested in an arctic area. The method is used to analyse the seasonal and regional variation in the snow cover depletion, and an example of its application to a wildlife study is given.

The NOAA-AVHRR is a meteorological sensor originally designed for detecting clouds and surface temperature over large areas. It was first launched into a near-polar, sun-synchronous orbit in 1978. Channels $1(0.56-0.68 \mu \mathrm{m})$ and $2(0.725-$ $1.10 \mu \mathrm{m})$ measure reflect solar radiation, whereas channel $3(3.55-3.93 \mu \mathrm{m})$ measures in the mid- 
infrared band and channel $4(10.3-11.3 \mu \mathrm{m})$ and $5(11.5-12.5 \mu \mathrm{m})$ measure in the thermal infrared bands (Lauritson et al. 1988). Above highly reflective snow and ice masses, the AVHRR sensors, with their ten-bit radiometric resolution, are significantly less affected by saturation (overexposure) problems than the eight-bit radiometric resolution of the Landsat Multi-Spectral Scanner and Thematic Mapper and the SPOT High-Resolution Visual sensors. Though AVHRR is characterised by a coarse spatial resolution $(1.1 \mathrm{~km}$ at nadir), it is favoured by a wide swath (approximately $3000 \mathrm{~km}$ ) and two satellites orbit every 6 hours. Subsequent and future satellites in the NOAA series will ensure extensive archieving of data, although the effectiveness of the instrument as a tool for mapping surface features is limited when there is cloud cover (Masson 1991).

Persistent cloud cover comprising thin, lowaltitude stratus, haze and fog prevail along the eastern coast of Greenland at times of snowmelt. But poleward of $70^{\circ} \mathrm{N}$, the overlap of the NOAAAVHRR orbit is large enough to guarantee the coverage of a particular point on at least three consecutive afternoon passes, rendering the imagery useful in the gathering of surface data in the few, short, cloud-free periods.

\section{Study area}

The peninsula of Jameson Land, located from $70^{\circ} 30^{\prime} \mathrm{N}$ to $72^{\circ} \mathrm{N}$, measures $10,000 \mathrm{~km}^{2}$. It is bounded to the northwest, north and east by fjords and alpine ice-capped mountain ranges and to the south-southeast by Scoresby Sund (Fig. 1). The study area comprises a plateau which dips westwards at an angle of $3^{\circ}$ to $5^{\circ}$ forming 500 to $600 \mathrm{~m}$ high cliffs along its eastern border while sloping gently towards Scoresby Sund in the western. In the northern and eastern parts of the peninsula, broad valleys are common, whereas the rest of the study area is slightly undulating with gullies associated with numerous drainages.

The climate in the central part of Jameson Land is low-arctic with mean air temperature above $5^{\circ} \mathrm{C}$ in the warmest months (July). The climate in the coastal areas is high-arctic with mean air temperatures below $5^{\circ} \mathrm{C}$ in the warmest month (July) partly because of the proximity of the Polar Ice Drift (Nuna-Tek 1989). Ice causes frequent foggy conditions all along the coastal zone extending up into the valleys. The central part of Jameson
Land is continental with an annual precipitation between $300-400 \mathrm{~mm}$, whereas the precipitation in the coastal areas is between $500-600 \mathrm{~mm}$. The precipitation is equally distributed throughout the year with approximately half falling as snow in the winter months (November to April). Strong northerly winds during the winter season redistribute the snow cover to form snowdrifts on the southfacing sides of hills and drainages, leaving thin or no snow cover on the windswept northfacing slopes.

For the period 1950-1986, accurate snow depth measurements are only available for Mestersvig station, north of the study area (Fig. 1). After that time the registration succeeded at Constable Pynt, which is to the southeast of the study area. The registration was undertaken by untrained personnel, so the quality of the data is very varied with no data for long periods in some years. Snow cover data from some of the continuously recorded years is shown in Table 1. In most years, persistent snow cover is registered during the last two weeks of September, and the snow depth gradually increases during October, November and December. For the period 1954-1987, average snow depth exceeded $1 \mathrm{~m}$ during at least 3 of the winter months and in some years even exceeded $2 \mathrm{~m}$. In years with shallow snow depths, the snow cover has melted away by the end of June; in years with a thick snow cover, the last snow drifts last until the end of July or the first week of August.

The vegetation of the even, central part of Jameson Land is dominated by continuous dry dwarf scrub heath (Mosbech \& Hansen 1994). The flat inland plateau and the coastal zone are dotted with small lakes and ponds near luxuriant graminoid fens. Snowbed and herb-slope vegetation are characteristic in the lower parts of southfacing slopes which receive ample water supply throughout the summer from the melting of the upslope snowdrifts. Windswept ridges and the more elevated eastern and northern parts of Jameson Land are dominated by fell-field with sparse vegetation or bare ground.

In Jameson Land, a population of muskoxen (Ovibos moschatus) has been inconsistently - observed during this century (Thing et al. 1987), but recently, prior to and during oil exploration (Mosbech \& Glahder 1990), populations of moulting barnacle geese (Branta leucopsis) and pink-footed geese (Anser brachurhuncus) (Madsen \& Mortensen 1985) have been included in the 


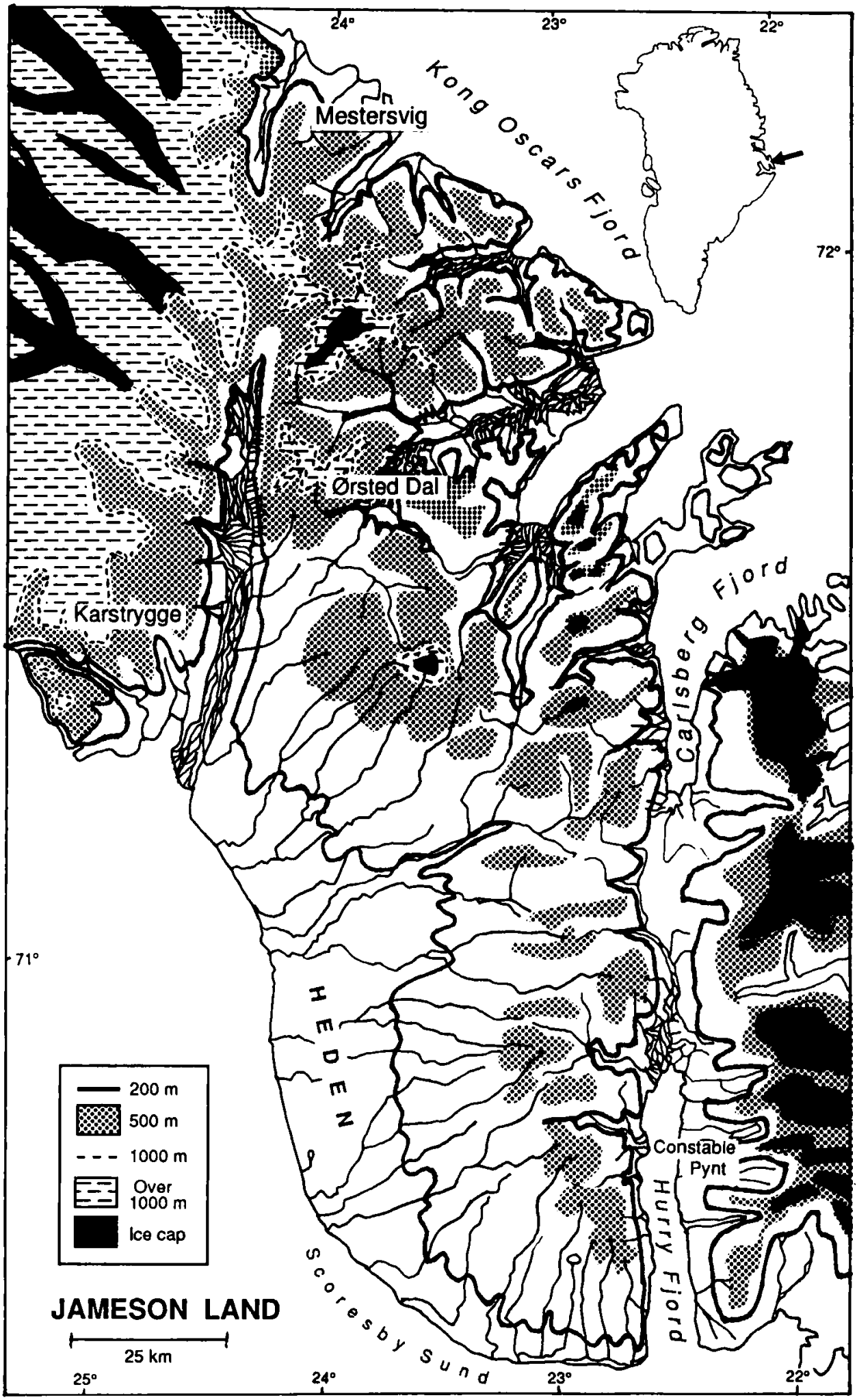

Fig. l. Map of Jameson Land and surrounding area. 
Table 1. Data on calf crop, monthly snow depth and duration of snow cover from Mesters Vig (1954-1986) and Constable Pynt (1987). Calf prod data from different surveys from 1954 to 1984 are summarised in Sittler (1988), while data from the period 1984 1987 are summarised in Aastrup (1988) and Aastrup \& A. Mosbech (1988).

\begin{tabular}{|c|c|c|c|c|c|c|c|c|}
\hline \multirow[b]{2}{*}{ Year } & \multirow{2}{*}{$\begin{array}{l}\text { calf } \\
\text { crop, \% }\end{array}$} & \multicolumn{6}{|c|}{ Monthly snow depth } & \multirow{2}{*}{$\begin{array}{l}\text { Number of days } \\
\text { with a registered } \\
\text { snow cover after } \\
1 \text { January }\end{array}$} \\
\hline & & D & $\mathbf{J}$ & $\mathbf{F}$ & $\mathbf{M}$ & $\mathbf{A}$ & $\mathbf{M}$ & \\
\hline 1954 & 1.5 & 170 & 190 & 210 & 220 & 240 & 220 & 220 \\
\hline 1961 & 23.6 & 45 & 67 & 90 & 102 & 95 & 35 & 179 \\
\hline 1962 & 5.6 & 115 & 150 & 180 & 140 & 125 & 110 & 199 \\
\hline 1974 & 3.0 & 45 & 175 & 175 & 170 & 160 & 120 & 206 \\
\hline 1979 & 21.6 & 30 & 55 & 50 & 80 & 50 & 20 & 171 \\
\hline 1979 & 25.3 & 30 & 55 & 50 & 80 & 50 & 20 & 171 \\
\hline 1980 & 6.5 & 118 & 155 & 125 & 150 & 180 & 110 & 202 \\
\hline 1982 & 15.5 & 40 & 45 & 80 & 135 & 110 & 100 & 187 \\
\hline 1982 & 19.8 & 40 & 45 & 80 & 135 & 110 & 100 & 187 \\
\hline 1984 & 19.0 & 40 & 70 & 110 & 140 & 120 & 110 & 190 \\
\hline 1984 & 15.0 & 40 & 70 & 110 & 140 & 120 & 110 & 190 \\
\hline 1985 & 7.5 & 75 & 110 & 105 & 135 & 125 & 120 & 203 \\
\hline 1986 & 24.0 & 10 & 20 & 35 & 85 & 65 & 40 & 160 \\
\hline 1987 & 14.4 & 60 & 60 & 130 & 150 & 130 & 100 & 191 \\
\hline MEAN & 14.5 & 61 & 91 & 109 & 133 & 120 & 94 & 190 \\
\hline
\end{tabular}

monitoring. The population levels, distribution and muskox calf crop have been monitored to evaluate whether the oil exploration has had an impact on them. Snow cover is considered to be a very important factor affecting muskox mortality, reproduction and distribution (Vibe 1967; Sittler 1988; Gunn et al. 1991). The Jameson Land muskox population has fluctuated between 2300 and 5000 animals since 1981 (Boertman et al. 1992; Aastrup \& Mosbech 1993) when the annual surveys began. This is the southernmost occurrence of muskoxen on the eastern coast of Greenland. The population is only able to survive because the average winter precipitation is low and thaws associated with rain which cause severe ice crust on snow surfaces are exceedingly rare. According to reports from expeditions and hunters (Vibe 1967), the muskox population in northern and eastern Greenland increased steadily until 1938. In the winter of $1938 / 39$, the mild and wet weather, with rainy periods which formed ice crust on the snow cover, caused considerable losses to the population as the animals could not break through the crusts to reach the vegetation underneath. Similar winters with greater or lesser losses occurred five times in the 1940s and 1950s; but the worst and most geographically widespread winters known to date were in the 1938/39 and 1953/54 (Vibe 1967).

\section{Satellite data processing}

The NOAA-AVHRR satellite data have been selected from data archives at the receiving station in Dundee, Scotland. The image processing of the satellite data was carried out using the CHIPSsystem (Holm et al. 1988) developed at the Institute of Geography, University of Copenhagen. NOAA imagery is available on a daily basis at very reasonable costs, and is therefore well suited for snow monitoring. The approximately $1 \times 1 \mathrm{~km}$ resolution is adequate for snow mapping areas larger than $100-500 \mathrm{~km}^{2}$ (Thomsen 1985). During the melting season, cloud-free scenes of the study area are rather rare; so to achieve the best time sampling, every suitable scene must be used and then corrected radiometrically and geometrically.

An automatic filtering procedure is used to remove cloud- and haze-contaminated pixels to minimise misinterpretation and reduce computing time later on. Cloud coverage determination has been developed as an easily applicable, step by step routine that utilises simple threshold algorithms. A combination of surface temperatures determined by the "split-window"-technique and the T3-T4 values removes cloud pixels, whereas the difference between brightness temperatures in channels 4 and 5 , on the basis of empirically 
determined thresholds, is used to remove pixels contaminated by haze and semi-transparent clouds (Hansen 1990). The T3-T4 value is defined as the difference between brightness temperatures in channels 3 and 4 . It has proved very useful in the cloud classification process (Liljas 1989) due to the marked difference between T3-T4 values calculated for clouds as opposed to T3-T4 values calculated for other surfaces. The reflection of solar radiation from clouds in the electromagnetic spectrum covered by channel 3 (3.55$3.93 \mu \mathrm{m})$ is minimal because water vapour absorbs a great deal of the emitted solar radiation in this part of the spectrum.

In geometrical correction, both a systematic correction of the panoramic effect and a transformation to UTM-model by a cross-correlation technique were used to achieve high sub-pixel accuracy, which is very important in multitemporal classification. The radiometric correction starts with the calculation of surface albedo, $A_{u c}$ by using the standard NOAA algorithm on raw data counts in channel 1 :

$$
\mathrm{A}_{u c}=\frac{\text { gain }{ }^{*} \text { raw counts (channel 1) }}{\sin \mathrm{h}}+\text { intercept }
$$

Gain and intercept are the tabulated pre-launch calibration coefficients (given in Lauritson et al. $1988) ; \sin h$ is the sine to solar elevation angle (h) at the time of the overpass.

No separation between planetarian and surface albedo has been made as the atmospheric attenuation is considered of minor importance in arctic areas. Previous investigations (Hansen 1991) have shown that the surface albedo is only minimally influenced by the atmosphere, when the sun elevation is above $30^{\circ}$ and the view angle is less than $40^{\circ}$. During the arctic winter, when the sun does not rise over the horizon, snow monitoring can not be carried out; but in the period 10 April-1 September, the sun elevation is above $30^{\circ}$ at the time of the afternoon overpass (NOAA 9 and 11), which allows snow monitoring to be carried out easily.

When correcting for the varying input of solar radiation at the surface, depending on slope and aspect, a trend surface has been computed around each point in the terrain model (Thomsen 1985; Søgaard \& Thomsen 1988). For each point the linear trend surface is fitted through the point and the neighbouring eight points. The normal vector to the point is determined by simple arithmetic and in the same coordinate system the direction towards the sun can be expressed as a unit vector. The cosine of the solid angle ( $\cos v)$ between the two directions is calculated as

$$
\cos \mathrm{v}=\cos \mathrm{z} \cos \mathrm{e}+\sin \mathrm{z} \sin \mathrm{e} \cos \mathrm{a}
$$

where $\mathrm{z}$ is the solar zenith angle, $\mathrm{e}$ is the surface slope angle, and $a$ is the difference between the sun's azimuth and the slope aspect.

This expression allows the calculation of the direct part of the total radiation. Field measurements have shown that the diffuse part of the radiation is practically independent of slope, and because this part constitutes approximately $20 \%$ of the total radiation on clear days in Greenland (Thomsen 1985), the following expression can be formulated for deriving the slope-corrected albedo, $\mathbf{A}_{c}$ :

$$
\mathrm{A}_{c}=0.2 * \mathrm{~A}_{u c}+0.8 * \mathrm{~A}_{u c} * \frac{\sin \mathrm{h}}{\cos \mathrm{V}}
$$

The slope correction is important to avoid underestimating the surface albedo on northfacing slopes and overestimating it on southfacing slopes.

\section{Snow-cover mapping}

The snow-cover mapping can be performed with the direct use of the slope-corrected albedo values as the albedo for a fully snow covered area only depends on local topography in the melting season (Søgaard \& Thomsen 1988). During the winter and the early spring, a fully mature snow cover has surface albedos between 0.70 and 0.75 ; but when the snow cover starts to break up, the albedo value decreases towards a lower limit fixed by the albedo of the underlying surface. This value denotes the background albedo. In each pixel, the slope-corrected albedo $\left(A_{c}\right)$ is expected to be a mixture of the albedo of full snow cover $\left(A_{s}\right)$ of fraction $S$ and the background albedo $\left(A_{b}\right)$ of the snowfree surface with the fraction (1-S).

The snow cover can then easily be calculated by a simple arrangement of the terms according to the expression

$$
\text { snow cover }=\frac{A_{c}-A_{b}}{A_{s}-A_{b}} .
$$

The validity of the above expression in arctic areas has been tested both by means of hydrolog- 


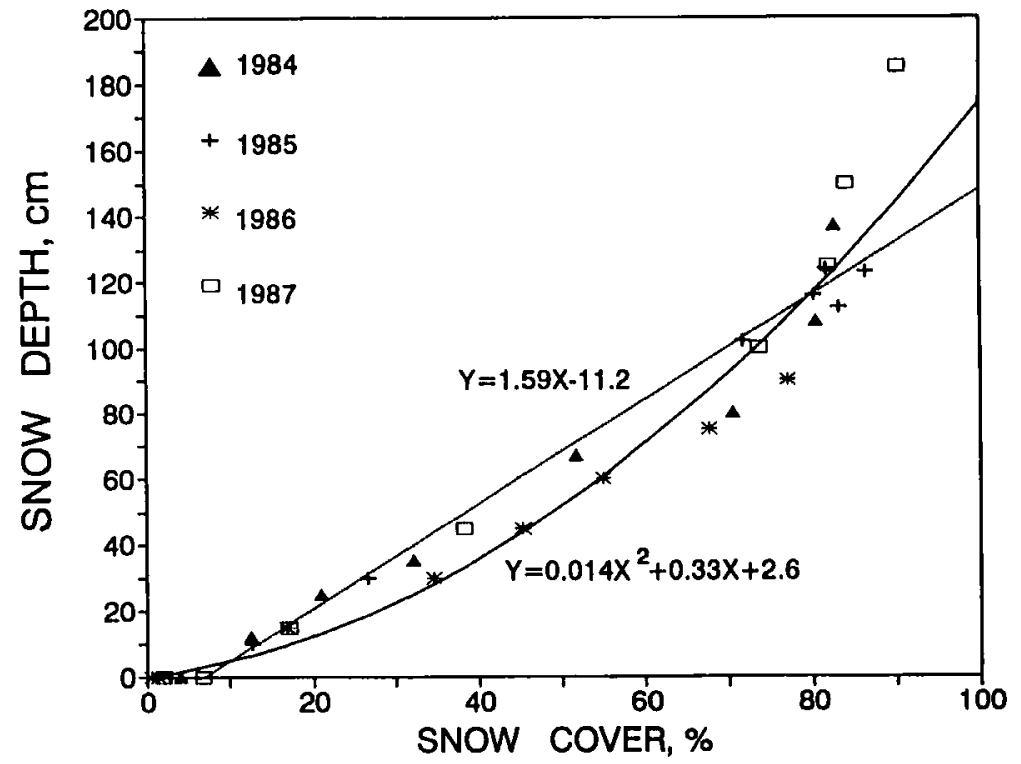

Fig. 2. Scatterplot showing the relationship between snow cover percentage derived on basis of NOAA-AVHRR data and snow depth measured at Mesters Vig during the melting season April-July 1984 to 1987. ical studies (Søgaard \& Thomsen 1986) and field studies (Søgaard 1985). Snow-cover values monitored by satellite can also be used to estimate the snow depth (Fig. 2). For snow cover/snow depth relationships, a linear correlation coefficient of 0.92 and maximum curve correlation coefficient of 0.96 were derived. Fig. 2 shows that small increases in snow depth lead to significant increases in the snow cover due to the gradual disappearance of the snow-free patches, but above $50 \mathrm{~cm}$ no significant change in the snow cover occurs. Maximum snow depths, beyond which further snow cover increase is minimal, were estimated to be $30 \mathrm{~cm}$ (McGinnis et al. 1975) and $50 \mathrm{~cm}$ (Dozier 1987) for monitoring in North Dakota and the Sierra Nevada in the United States, and $30 \mathrm{~cm}$ for areas monitored in northern Finland (Kuittinen 1988). The high threshold value at Mestervig is due to the very uneven surface topography (broken ground with large boulders) which is not covered before the snow depth exceeds $50 \mathrm{~cm}$. McGinnis et al. (1975) and Kuittinen (1988) calculated maximum curve correlation coefficients of 0.86 and 0.89 from data from several stations in large areas, so the high correlation coefficient of 0.96 in Fig. 2 substantiates the use of snow-cover data to estimate both the duration and magnitude of snow cover during the melting season.

\section{Spatial distribution of snow cover}

A total of 45 NOAA-AVHRR subscenes from the melting season (April-July) have been selected for the years 1984 to 1987. Figs. 3, 4 and 5 show stages in the regional variation of snow cover depletion in the winter $1983 / 84$. This was a normal year (Table 1), and a 90-100\% snow cover was maintained in most parts of the area until the end of April. Fig. 3 indicates the snow distribution on 13 May at the start of the melting season. The snow cover in Ørsted valley and in the central parts of Heden 1 (Fig. 6) was only $40-60 \%$ as the snow cover in these areas had been removed by the strong northerly winds during the late winter season. In mid-June the snow cover dropped below $50 \%$ for much of the study area (Fig. 4), and in the lower and warmer central parts of Heden 1 and in $\emptyset$ rsted valley the snow cover was below $20 \%$. Continuous snow coverage was, and still is, only found in areas above $1000 \mathrm{~m}$. The fast depletion rate in late June implied a reduction to less than $20 \%$ snow coverage by the beginning of July (Fig. 5), and at the end of July the snow coverage for the entire study area was below 5\%.

During the monitoring of the muskox population, Jameson Land was divided into five subareas (Fig. 6) (Aastrup \& Mosbech 1988). The average snow cover percentage in each of the five 


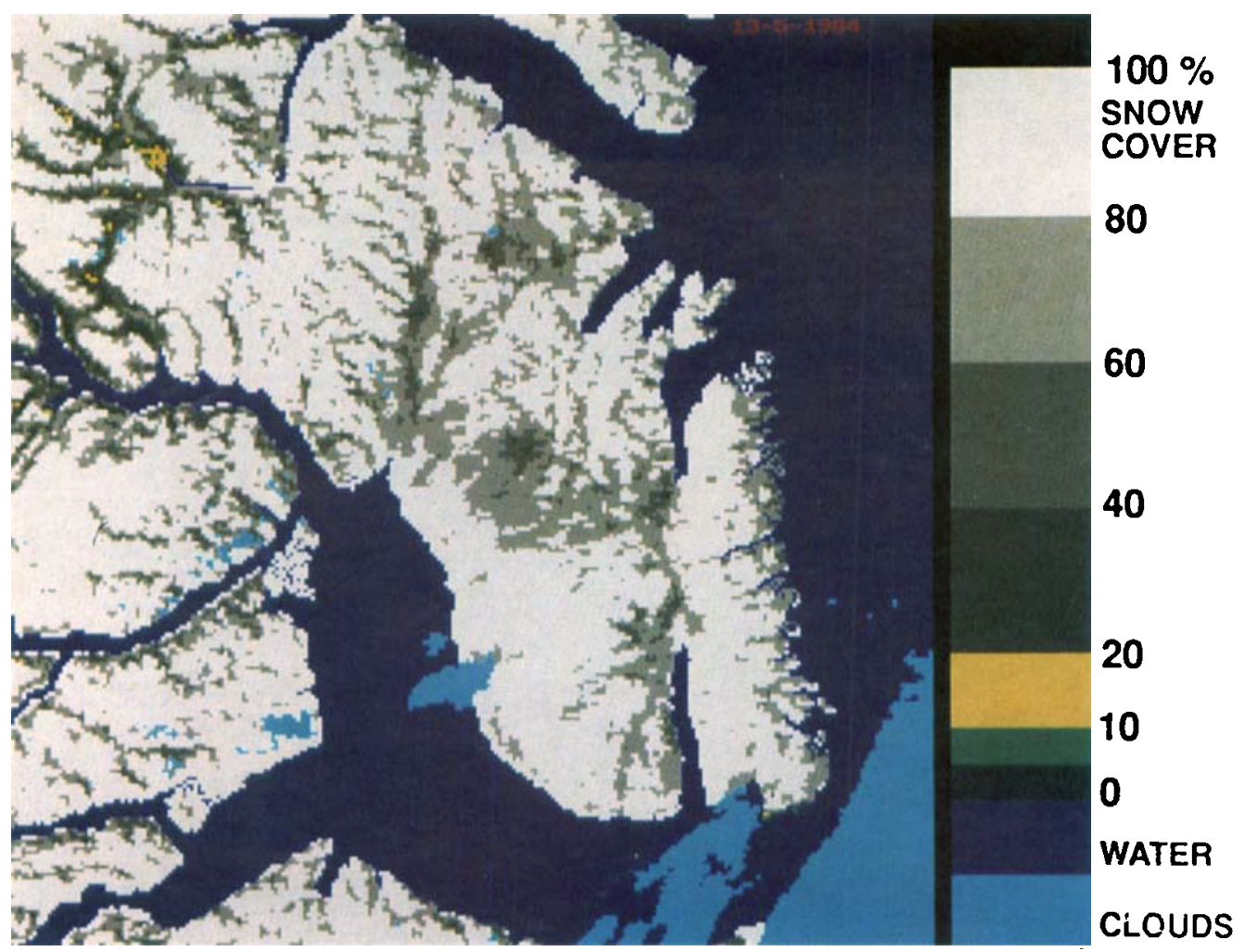

Fig. 3. The geographical distribution of the snow cover percentage in Jameson Land, 13 May 1984.

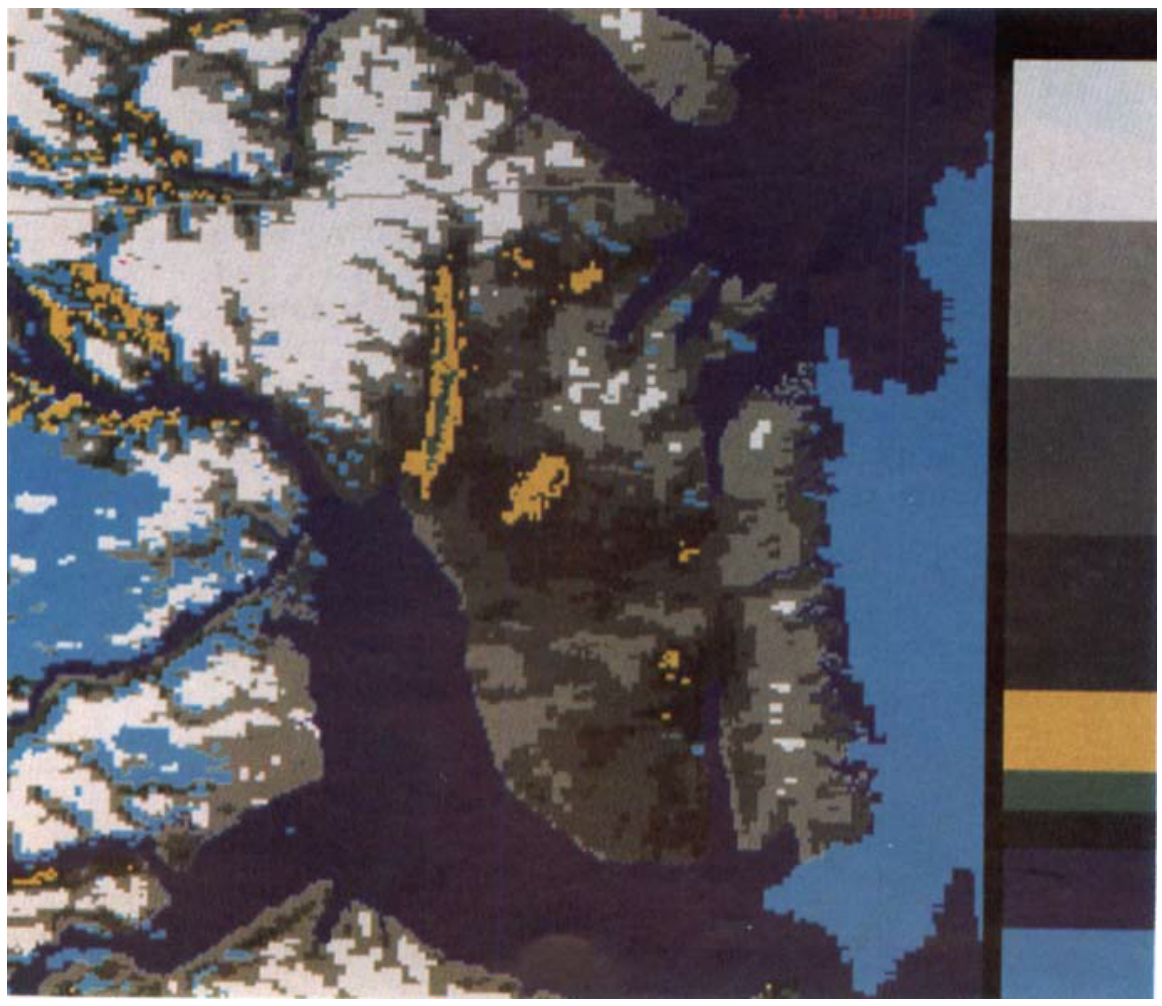

$100 \%$

SNOW

COVER

80

60

40

20

10

0

WATER

CloudS

Fig. 4. The geographical distribution of the snow cover percentage in Jameson Land, 11 June 1984. 


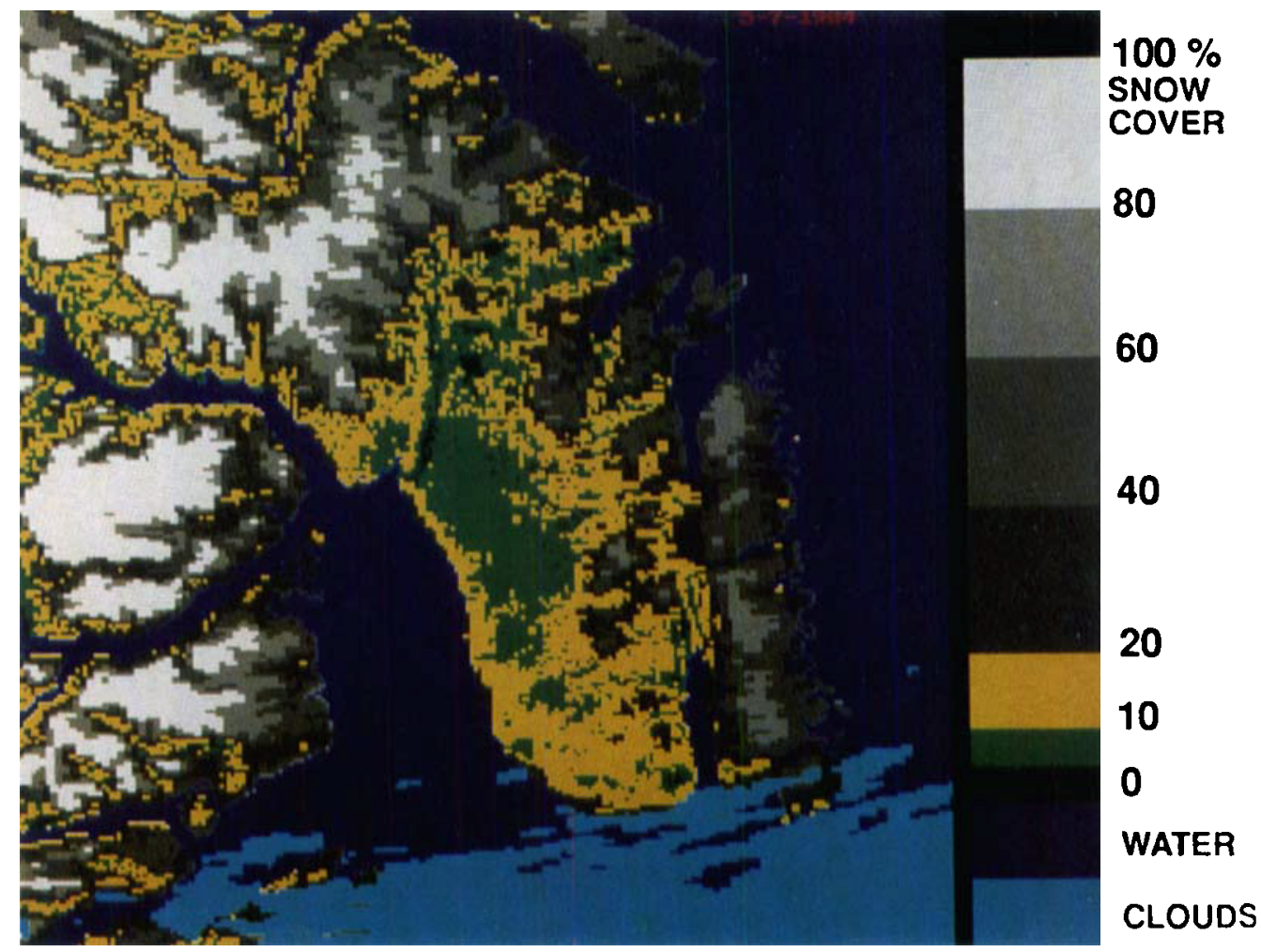

Fig. 5. The geographical distribution of the snow cover percentage in Jameson Land, 5 July 1984.

subareas was analysed and the results for April and May are shown in Fig. 7 and for June and July in Fig. 8. F- and t-tests were used to determine if there was any significant variation in the monthly snow coverage in the five subareas from one year to another. The statistical analyses showed no significant difference ( $5 \%$-level) in the snow coverage in April 1985 and April 1987, whereas a subsequent chi-square test showed a significant difference (5\%-level) in the regional distribution of the snow coverage over the course of the two years. For the month of May there was no significant difference in the snow cover between 1984 and 1986. In June, a significant variation was only found between 1985 and 1986 and between 1986 and 1987, whereas in July, a significant variation was found for all combinations for all years.

Contrary to the normal winter $1983 / 84$, the winter $1984 / 85$ was very cold with a thick, protracted snow cover, and the following growing season was very short and cold. The snow cover in April and May 1985 (Fig. 7) was the' highest of all four winters in all five subareas. The winter
$1985 / 86$ was mild with a very thin snow cover (Table 1), which quickly melted away in June. The snow cover in 1986 was the lowest in all five subareas in almost each of the four months (Fig. $7 \& 8$ ). The regional distribution of the snow cover in the last winter $(1986 / 87)$ was very atypical in comparison with the previous three winters. In the southern areas, snow cover was below average in April and May (Fig. 7), whereas in the northern parts it was above average. June 1987 was a very cold month and the snow melting decreased, so that the snow cover for this month ranged between 35 and 55\%, even higher than June 1985. In all four winters, Heden 1 and the two northern areas, Karstryggen and $\emptyset$ rsted valley, had less snow than the average for the entire area, whereas the two southern areas, Heden 2 and 3 , had above average snow cover.

\section{The influence of snow cover on muskoxen in Jameson Land.}

The number and distribution of muskoxen in 


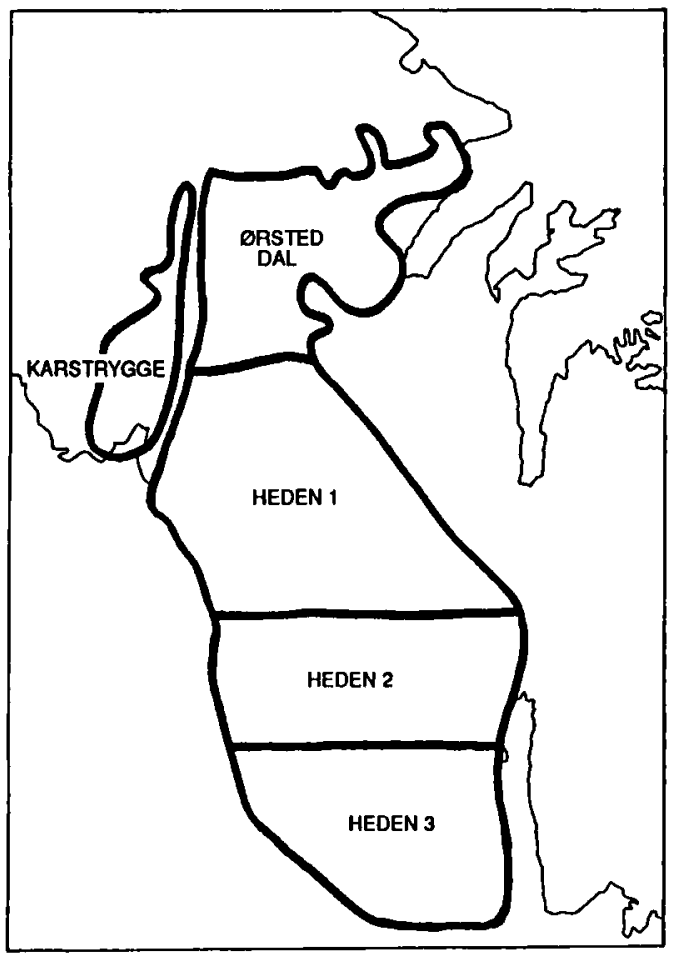

Fig. 6. Jameson Land divided into five subareas used in the muskox monitoring.
Jameson Land were recorded during aerial surveys using fixed-wing aircraft (Aastrup \& Mosbech 1993). The surveys were carried out in March or April when the ground was nearly $100 \%$ covered by snow. From an altitude of $200-300 \mathrm{~m}$ above the ground, the dark outlines of the animals are easily spotted against the bright surface. Fig. 9 shows the percentage of muskoxen distributed in the five previously mentioned subareas (Fig. 6). Chi-square tests on muskox distribution in the four years show no significant variation in the distribution between 1984 and 1986 (5\% level), unlike all the other combinations. The total number of counted muskoxen was nearly 3000 in 1984 and 4000 in 1985 , but fell by approximately 1000 in each of the following years.

The high correlation between snow coverage and snow depth in Fig. 2 supports the use of regional snow-cover monitoring as an estimator of regional snow depth variation. Snow-cover data for April and May (Fig. 7) can be used to explain the distribution of muskoxen at the time of the aerial surveys, whereas snow cover data for June and July (Fig. 8) are inappropriate for explaining the distribution of muskoxen in MarchApril.

The region Heden 1 has $38-58 \%$ of the muskox
Fig. 7. Average snow cover percentage in April and May for the five subareas used in the muskox monitoring (Fig. 6). $\mathrm{H} 3=$ Heden $3, \mathrm{H} 2=$ Heden $2, \mathrm{Hl}=$ Heden 1 , $\emptyset=\emptyset$ rsted valley and $\mathrm{K}=$ Karstryggen.
APRIL MAY

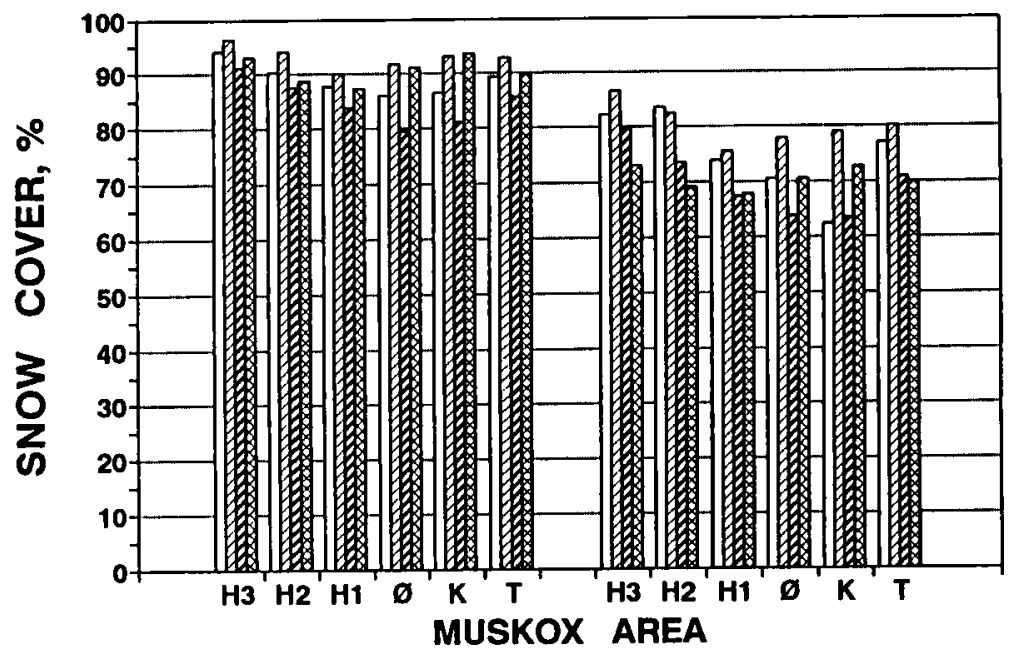

1984 UIZ 1985 WII 1986 
population in all years and has little snow cover in April and May compared with the other areas. Karstryggen and $\varnothing$ rsted valley exhibit great internal variations in the snow cover, with values down to 50\% in April and 30\% in May on windswept ridges; the relative share of muskoxen is $10-30 \%$ in these two areas. In general, the snow cover in the two southern areas is high with very little internal variation, and the muskox number in these areas never exceeds $10 \%$ of the total population in Jameson Land. In a mild winter with thin snow cover $(1985 / 86)$, the muskox distribution was more scattered, and the number of muskoxen in Heden 1 dropped to $38 \%$ of the total population. In a winter with thick snow cover $(1984 / 85)$, the muskoxen were concentrated $(56 \%)$ in the central area, Heden 1 , which generally has the thinnest snow cover, but relatively large numbers were also found on windswept ridges in Ørsted valley (21\%) and on Karstryggen $(16 \%)$. In a winter (1986/87), which had a thick, longlasting snow cover in the two northern areas, the muskoxen also tended to concentrate in the central area (Heden 1), where the snow cover was thin.

Sittler (1988) studied muskoxen in the region just north of Jameson Land $\left(72-74^{\circ} \mathrm{N}\right)$. When making a comparison of the data on muskox calf crop and data on snow depth from December to May for the Mesters Vig area, he found a highly negative correlation $(r=0.915)$. Similarly, in a year with thick snow cover in Jameson Land (1984/85), muskox calf crop was low (7.5\% of the population, Table 1), but in a year with thin snow cover (1985/86) calf crop was high $(24.0 \%)$. As a high correlation ( $r=0.96$ ) exists (Fig. 2 ) between snow depth and the satellite-monitored snow cover at Mesters Vig, it is obvious to correlate the calf crop with the number of days with a registered snow cover at Mesters Vig (Tab. 1). Fig. 10 shows a high linear correlation $(r=0.92)$, and a curvilinear regression (Gauss integral) describes the relationship between snowdays and calf crop even better (provided the number of snowdays from 1 January are normally distributed). An examination of the average snow cover around Mesters Vig during the four winters (1984-1987) gave a result very close to the average for the five muskox subareas in Fig. 6. Although it is difficult to transform the number of registered snowdays to satellite monitored snow cover, the figures indicate higher calf crop in years with shortlasting snow cover and a lower calf crop in years with longlasting snow cover. Other factors, such as short and cold growing seasons and ice crusts, might also influence the physical conditions of

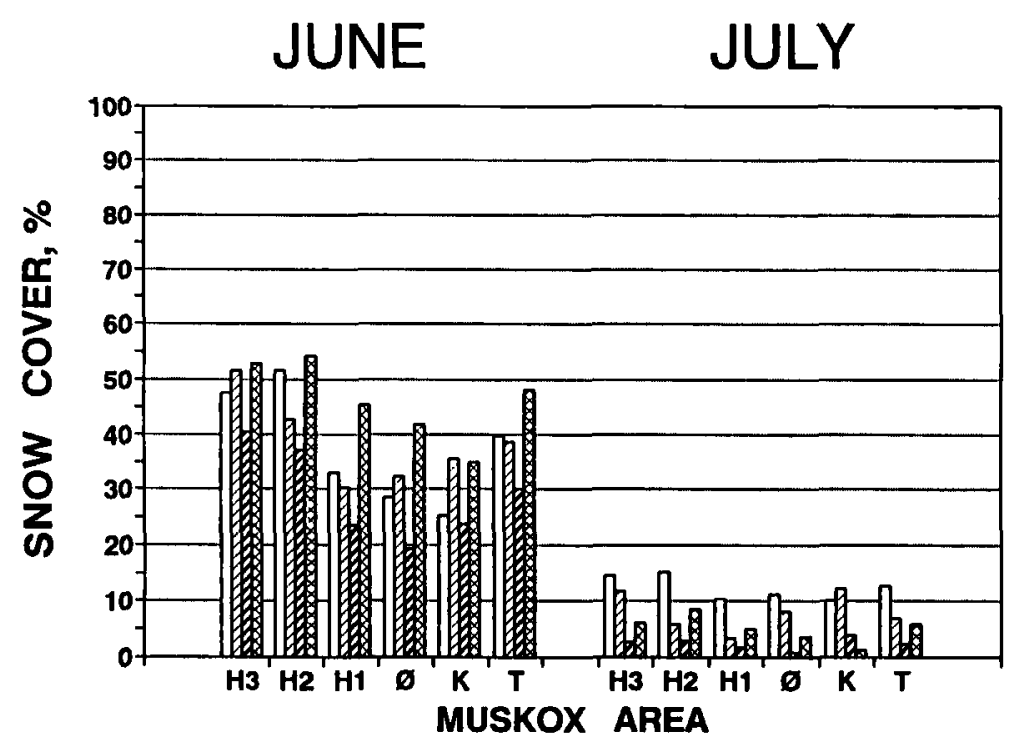

1984 ZIA 1985 QIIA 1986
Fig. 8. Average snow cover percentage in June and July for the five subareas used in the muskox monitoring (Fig. 6). $\mathrm{H} 3=$ Heden $3, \mathrm{H} 2=$ Heden $2, \mathrm{H} 1=$ Heden 1 , $\emptyset=\emptyset$ rsted valley and $\mathrm{K}=$ Karstryggen. 
Fig. 9. Relative distribution of muskoxen in the five subareas (Fig. 6) on Jameson Land in April in 1984-1987. $\mathrm{H} 3=$ Heden $3, \mathrm{H} 2=$ Heden 2, H1 = Heden 1 , $\emptyset=\emptyset$ rsted valley and $K=$ Karstryggen.
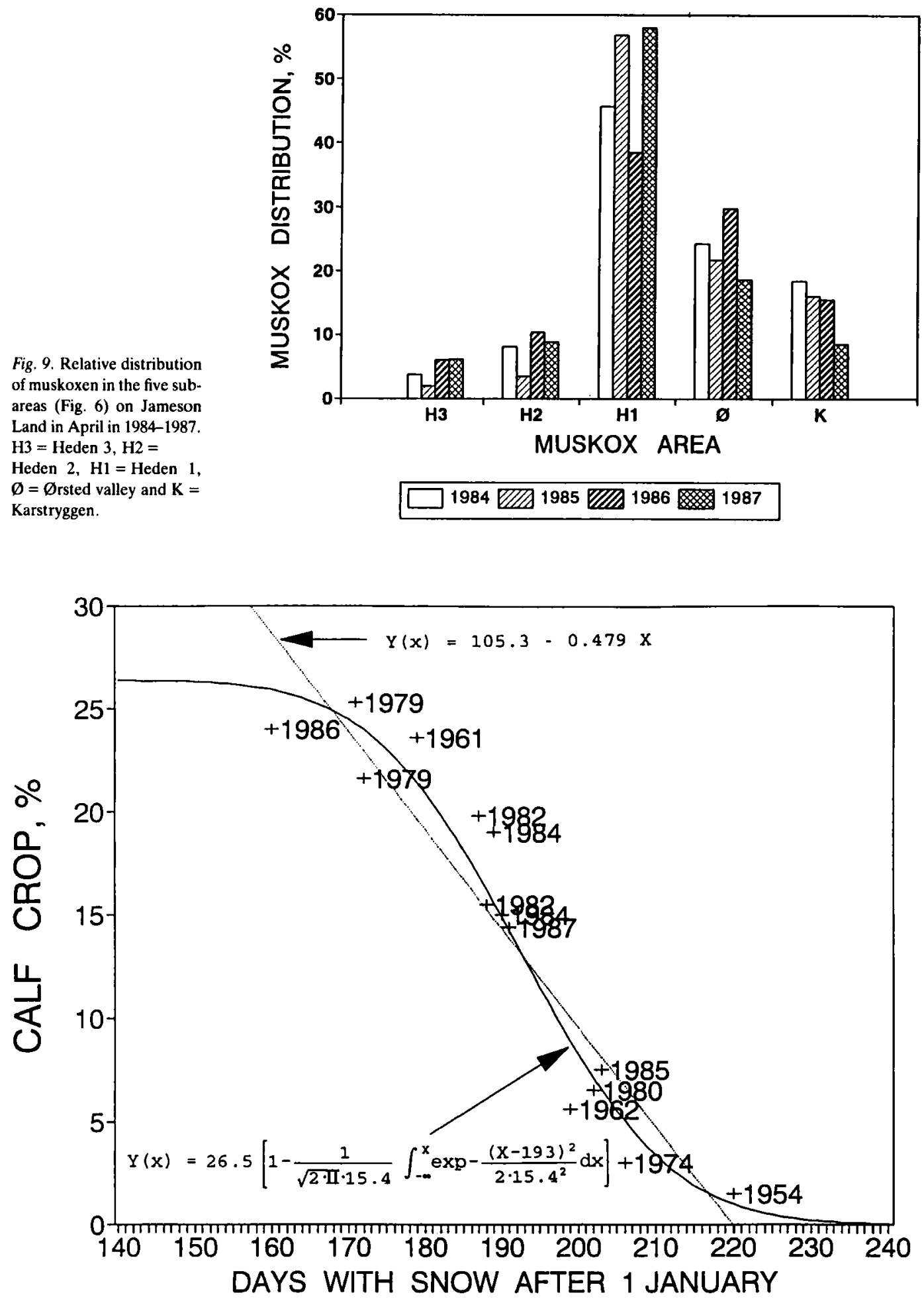

Fig. 10. Relation between calf crop (\%) and the number of days with a registered snow cover after 1 January at Mesters Vig (data referred to are listed in Tab. 1). 
muskox cows and consequently influence the calf crop (surveyed in August). In the eleven years described in Table 1, short, cold growing-seasons always followed long winters and long, warm growing-seasons followed short winters. Severe ice crusts were only registered in association with the heaviest snow cover in 1954.

Several studies have underlined the importance of snow cover to the distribution, behaviour and calf crop of muskoxen (Vibe 1967; Freemann 1971; Sittler 1988). Lately Gunn et al. (1991) discussed muskoxen population fluctuations on Banks Island. The research suggested that the severity of winter snow conditions may determine annual mortality, but plant phenology and the duration of the plant growing-season may determine calf crop rates. Unusually adverse snow conditions resulted in noticeably reduced calf crop among reindeer populations on Svalbard (Reimers 1982). Studies in Iceland (Fox et al. 1991) showed that the pattern and timing of snow thaw in spring can affect the availability of terrestrial resources such as food and nesting sites for breeding migrant pink-footed geese, which may influence the timing of the reproductive season and hence the reproductive success of these birds. However analysis of wildlife habitats covering smaller areas $\left(<1 \mathrm{~km}^{2}\right)$ implies that the NOAAAVHRR data must be combined with satellite data with finer spatial resolutions, i.e. Landsat TM and SPOT. Usually only one, if any, Landsat TM or SPOT satellite image of a specific area is available during the melting season; however, the frequent coverage by the NOAA-AVHRR offers an overall analysis of snow cover so as to place the Landsat TM or SPOT information within the regional and seasonal variation in snow cover depletion. Reeves et al. (1976) used AVHRR data combined with Landsat MSS data to monitor snow cover in arctic geese nesting areas and predicted the success of the breeding season in different areas of the North American Arctic.

\section{Discussion}

During the planning of hydro-power plants in Greenland, the use of NOAA-AVHRR data for snow cover monitoring has proved to be efficient and inexpensive. In spite of the coarse spatial resolution, the frequent coverage of specific areas makes the NOAA-AVHRR data useful for monitoring regional and seasonal variation in the snow cover and the data can easily be related to wildlife habitats covering large areas.

Normally the lack of cloud-free scenes in the melting season would hamper the method, but the cloud-masking routine enabled us to use partly cloud-free images, while the frequent satellite passages secured data from all cloud-free periods and interpolation between available images made snow cover mapping possible. A high correlation between snow cover percentage and snow depth was found, and the regional variation indicated the presence of a thinner and less durable snow cover in the central parts of Jameson Land where most years the highest concentration of muskoxen was found in the beginning of April. The study also showed a high correlation between early snowmelting and a high calf crop.

Moreover, the study has demonstrated the high value of satellite monitoring of remote northern regions, where access is difficult and travel expenses are high. The snow cover monitoring has proved useful in the interpretation of the regional distribution and reproductivity of muskoxen in Jameson Land. A combination of satellite data with high and low spatial resolutions will improve the method, making it even more useful in wildlife habitat studies restricted to small patches of terrain in both alpine and arctic areas.

\section{References}

Aastrup, P. 1988: Monitering af muskosokser i Jameson Land 1987. Greenland Environmental Research Institute. $21 \mathrm{pp}$.

Aastrup, P. \& Mosbech, A. 1988: Monitering af muskosokser i Jameson Land 1988. Greenland Environmental Research Institute. 39 pp.

Aastrup, P. \& Mosbech, A. 1993: Transect width and missed observations in counting muskoxen (Ovibos moschatus) from fixed-wing aircraft. Rangifer 13(2), 99-104.

Boertman, D., Forchhammer, M., Olesen, C. R., Aastrup, P. \& Thing, H. 1992: The Greenland muskox population status 1990. Rangifer 12(I), 5-12.

Dozier, J. 1987: Recent research in snow hydrology. Rev. Geophys. 25(2), 153-161.

Gunn, A., Shank, C. \& McLean, B. 1991: The History, Status and Management of Muskoxen on Banks Island. Arctic 44(3), 188-195.

Fox, A. D., Gitay, H., Boyd, H. \& Tomlinson, C. 1991: Snowpatch foraging by pink-footed geese Anser brachyrhynchus in south Iceland. Holarctic Ecol. 14(2), 81-84.

Freemann, M. M. 1971: Population characteristics of Muskoxen in the Jones Sound Region of the North West Territories. $J$. Wildl. Manage. 35(1), 103-108.

Hansen, B. U. 1990: Climate and vegetation analyses in southern Greenland using NOAA-AVHRR satellite data and field measurements. Ph.D. thesis, Institute of Geography, University of Copenhagen, p. 125 (in Danish). 
Hansen, B. U. 1991: Monitoring Natural Vegetation in Southern Greenland Using NOAA AVHRR and Field Measurements. Arctic 44 (Supp. 1), 94-101.

Holm. J., Olesen, H. H., Sandholt, I., Andersen, H. S. \& Rasmussen, K. 1988: CHIPS User's guide, Ver. 2.0. Copenhagen: Institute of Geography, University of Copenhagen. $150 \mathrm{pp}$.

Kuittinen, R. 1988: Determination of snow water equivalents by using NOAA-satellite images. Proceeding from the Seventh Northern Research Basins Symposium, Illulissat, Greenland, $159-168$.

Lauritson, L., Nelson, G. J., \& Porto, F. W. 1988: Data Extraction and Calibration of TIROS-N/NOAA Radiometers. NOAA Technical Memorandum NESS 107.

Liljas, E. 1989: Experience of an operational cloud classification method. Proceedings of the 4th NOAA AVHRR Data User's Meeting, Rothenberg, Germany, EUMETSAT, EUM PO6, 73-78.

Madsen, J. \& Mortensen, C. E. 1985: Habitat exploitation and interspecific competition of moulting geese in East Greenland. IBIS I29, 25-44.

Masson, R. 1991: Satellite Remote Sensing of Polar Regions. London. 308 pp.

McGinnis, D. F., Pritchard, J. A. \& Wiesnet, D. R. 1975: Determination of snow depth and snow extent fra NOAA-2 Satellite VHRR data. Water Resours. Re. 11(6), 897-902.

Mosbech, A. \& Hansen, B. U. 1994: Comparison of satellite imagery and infrared aerial photography as vegetation map- ping methods in an arctic study area; Jameson Land, East Greenland. This volume.

Mosbech, A. \& Glahder, C. 1990: Gdseundersøgelser i Jameson Land 1989. Greenland Environmental Research Institute. 50 pp.

Nuna-Tek 1989: Klima, Jameson Land. Forundersøgelser/ Misissueqqaarnerit, Copenhagen. $165 \mathrm{pp}$.

Reeves, H. M., Cooch, F. G. \& Munro, R. E. 1976: Monitoring arctic habitat and goose production by satellite imagery. $J$. Wildl. Manage. 40(3), 532-541.

Reimers, E. 1982: Winter mortality and population trends of reindeer on Svalbard, Norway. Arc. Alp. Res. 14(4), 295300.

Sittler, B. 1988: Distribution and Abundance of Muskoxen (Ovibos moschatus) in the North East Greenland National Park. Polarforschung 58(I), 1-12.

Søgaard, H. 1985: Snow-mapping in Greenland based on multitemporal satellite data. IAHS Publ. No. 145, 383-93.

Søgaard, H. \& Thomsen, T. 1988: Application of Satellite Data to Monitoring Snow Cover and Runoff in Greenland. Nordic Hydrol. 19, 225-236.

Thing, H., Klein, D. R., Jingfors, K. \& Holt, S. 1987: Ecology of Muskoxen in Jameson Land, Northeast Greenland. Holarctic Ecol. 10, 95-103.

Thomsen, A. 1985: Mapping Snowcover on a Microcomputer. Vannet i Norden 4, 85-103.

Vibe, C. 1967: Arctic animals in relation to climatic fluctuations. Medd. Gronland 170, 101 pp. 